\title{
Production of Oleic Acid Ethyl Ester Catalyzed by Crude Rice Bran (Oryza sativa) Lipase in a Modified Fed-batch System: A Problem and its Solution
}

\author{
Indro Prastowo ${ }^{* 1,3}$, Chusnul Hidayat ${ }^{1,2}$, Pudji Hastuti2 $^{2}$ \\ ${ }^{1}$ Postgraduate Program in Biotechnology, Postgraduate School, Gadjah Mada University, Jl. \\ Teknika Utara, Barek Yogyakarta 55281, Indonesia \\ ${ }^{2}$ Department of Food and Agricultural Product Technology, Faculty of Agricultural Technology, \\ Gadjah Mada University, Jl. Sosio Justisia, Bulaksumur, Yogyakarta 55281, Indonesia \\ ${ }^{3}$ Department of Biology Education, Faculty of Teacher Training and Education, Ahmad Dahlan \\ University, Kampus III, Jl. Prof. Dr. Soepomo, Janturan, Yogyakarta 55164, Indonesia
}

Received: 2nd May 2015; Revised: 20th June 2015; Accepted: 2nd July 2015

\section{Abstract}

A fed-batch system was modified for the enzymatic production of Oleic Acid Ethyl Ester (OAEE) using rice bran (Oryza sativa) lipase by retaining the substrate molar ratio (ethanol/oleic acid) at 2.05:1 during the reaction. It resulted in an increase in the ester conversion of up to $76.8 \%$ in the first $6 \mathrm{~h}$ of the reaction, which was then followed by a decrease from $76.8 \%$ to $22.9 \%$ in $6 \mathrm{~h}$ later. The production of water in the reaction system also showed a similar trend. The water was hypothesized to lead lipase to reverse the reaction which resulted in a decrease in both (water and esters) in the last $6 \mathrm{~h}$ of the reaction. In order to overcome the problem, zeolite powder $(25$ and $50 \mathrm{mg} / \mathrm{mL}$ ) were added into the reaction system at $5 \mathrm{~h}$ of the reaction. As the result, the final ester conversions increased drastically up to 90 95.7\%. Thus, the combination of a constant substrate molar ratio (ethanol/oleic acid) during the reaction (at 2.05:1) with the addition of zeolite powder $(25$ and $50 \mathrm{mg} / \mathrm{mL}$ ) to the reaction system at $5 \mathrm{~h}$ is effective for the enzymatic synthesis of OAEE. (C) 2015 BCREC UNDIP. All rights reserved

Keywords: Fed-batch system; rice bran (Oryza sativa) lipase; substrate molar ratio (ethanol/oleic acid); water; zeolite powder

How to Cite: Prastowo, I., Hidayat, C., Hastuti, P. (2015). Production of Oleic Acid Ethyl Ester Catalyzed by Crude Rice Bran (Oryza sativa) Lipase in a Modified Fed-batch System: A Problem and its Solution. Bulletin of Chemical Reaction Engineering \& Catalysis, 10 (3): 230-236.

(doi:10.9767/bcrec.10.3.8511.230-236)

Permalink/DOI: http://dx.doi.org/10.9767/bcrec.10.3.8511.230-236

\section{Introduction}

Recently, the application of biocatalysts in industry has been perpetually increasing since it does not involve high temperatures in its operation and is not harmful if discarded into the surrounding environment [1]. One of industrial

\footnotetext{
* Corresponding author.

E-mail:indro.prastowo25@gmail.com

Telp: (0274-563515)
}

enzymes is lipase (EC 3.1.1.3), which has an esterification activity and thus can be used as a biocatalyst for esterification reactions in some industries, e.g. foods, fragrances, biofuels, pharmaceuticals, biochemicals, oleochemicals, etc $[2,3,4]$. One of low-priced lipase sources is the rice bran (Oryza sativa) [5, 6].

The enzymatic reaction is always associated with a reaction system. One of the reaction systems is a fed-batch system. This system was reported to be more effective in producing a 
higher yield than the traditional reaction system, a batch system [6, 7]. The fed-batch system has also been modified in order to produce a higher yield [6]. Hidayat et al. [6] reported the application of high ethanol concentration at the initial reaction in a fed-batch system which was used to overcome a lipase inhibition by rice bran protease. However, the reaction only showed a higher ester conversion in early periods of the reaction, which was then followed by a saturation towards the end of reaction due to the inhibition of lipase by the presence of high ethanol concentrations in the reaction system [6]. Meanwhile, other authors reported that the esterification reaction rate increased drastically when the reaction was conducted at the optimum substrate molar ratio (alcohol/fatty acid) $[5,8]$.

Thus, the objective of this research was to modify the fed-batch system for the enzymatic synthesis of oleic acid ethyl ester using lipase from rice bran, in order to overcome the system's drawbacks and also to obtain a higher yield. The substrate molar ratio (ethanol/oleic acid) was constantly retained at 2.05:1 during the reaction. This ratio $(2.05: 1)$ was the optimum ratio which produced the highest yield [5]. Since water (a by product of the reaction) could reduce the reaction rate, the system was also including an addition of zeolite powder into the reaction system to absorb the water [9, $10,11,12,13]$. The ester conversion was then evaluated. The combination has been rarely carried out by any other researchers and information regarding to this is also very limited.

\section{Materials and Methods}

\subsection{Materials}

Rice bran from variety of Ciherang was purchased from a local supplier. Pyridine (99\%), oleic acid (99\%), acetone (99\%), isooctane (99.5\%), ethanol (96.9\%), and cupri-acetate (99\%) were purchased from Merck KGaA (Darmstadt, Germany). Meanwhile, zeolite powder (pore size 2.5-3 nm) was obtained from Sigma Co., (St. Louis, MO, USA).

\subsection{Enzyme preparations}

The crude enzyme was prepared according to Prastowo et al. [5] in which the rice bran (40 g) was first homogenized in a cold acetone (- 20 ${ }^{\circ}$ C) and then defatted in a Soxhlet for $30 \mathrm{~min}$ prior to storing at $-20^{\circ} \mathrm{C}$ until used.

\subsection{Methods}

2.3.1. Effect of A Constant Ratio (Ethanol/Oleic Acid) $(2.05: 1)$ on the Ester Synthesis

The enzymatic esterification reaction was carried out in a modified fed-batch system (Figure 1) in which the substrate molar ratio (ethanol/oleic acid) was first adjusted to a ratio of 2.05:1 by adding the appropriate amount of ethanol into a $200 \mathrm{~mL}$ of oleic acid solution (3.1 M). The defatted rice bran (29.58 g) was next added into the mixture. At the same time, another amount of ethanol and also oleic acid were fed into the mixture at $0.05 \mathrm{~mL} / \mathrm{min}$ and $0.26 \mathrm{~mL} / \mathrm{min}$, respectively. Furthermore, the

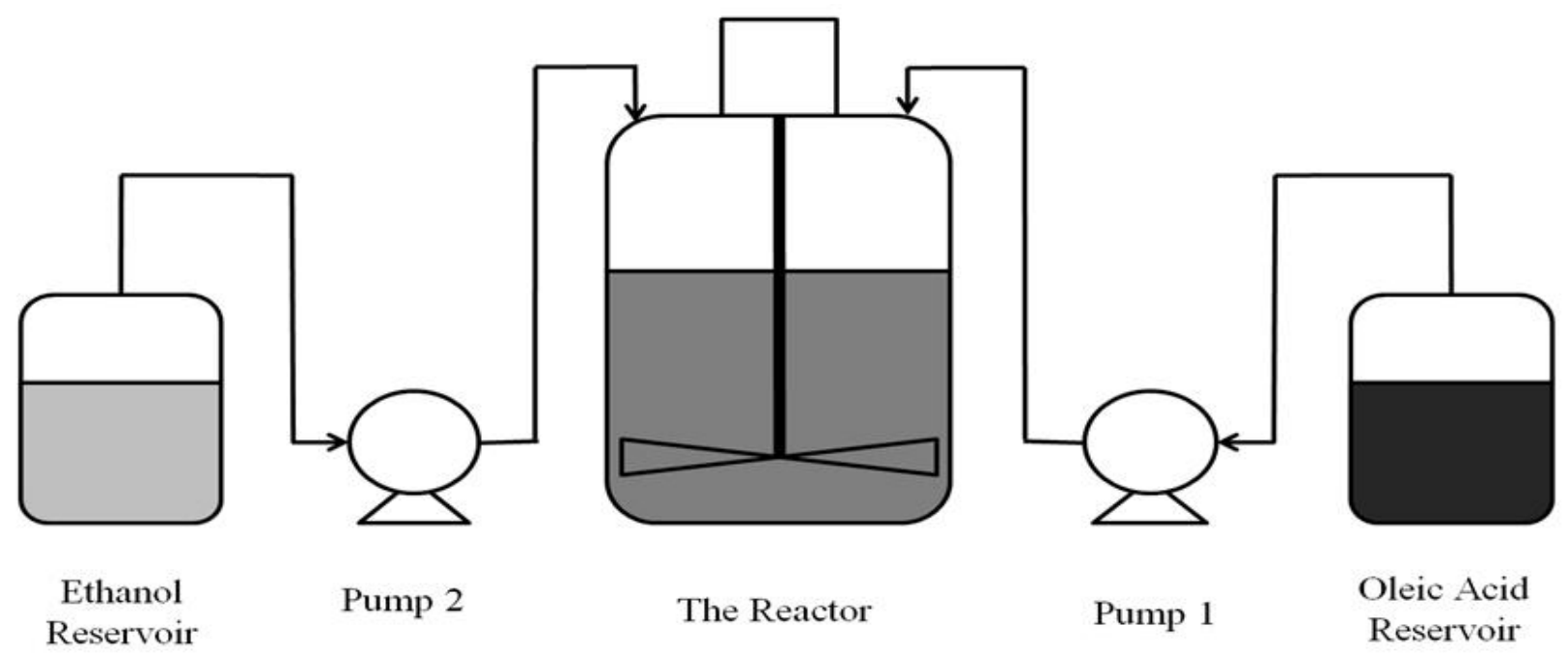

Figure 1. The schematic diagram of a modified fed-batch system used for an enzymatic esterification reaction of oleic acid ethyl ester catalyzed by lipase from rice bran (Oryza sativa). 
mixture was incubated at a room temperature $\left(30{ }^{\circ} \mathrm{C}\right)$ and then agitated at $1500 \mathrm{rpm}$ for $12 \mathrm{~h}$. The concentrations of ester, oleic acid, ethanol, water; and ester conversion were determined every $2 \mathrm{~h}$ during the reaction.

\subsubsection{Effect of zeolite powder addition on the ester synthesis}

The control was enzymatic esterification reactions which were carried out in a modified fed-batch system with the same reaction conditions as those applied in this research, but with the addition of zeolite powder at various concentrations ( 25 and $50 \mathrm{mg} / \mathrm{mL}$ ) at $5 \mathrm{~h}$ of the reaction (Figure 1). The concentrations of ester, oleic acid, ethanol, water; and ester conversion were then determined every $2 \mathrm{~h}$ during the reaction.

\subsubsection{Supporting experiment: effect of the wa-} ter concentration on the ester synthesis

This experiment was carried out in order to determine when zeolite powder should be added into the reaction system to produce the best results. The esterification reaction was carried out in a modified fed-batch system with the same reaction conditions as those applied in this research, but only carried out for $2 \mathrm{~h}$. Various concentrations of water $(0,10,20,30$, $40,50,60,70,80,90$ and $100 \%$ ) were later

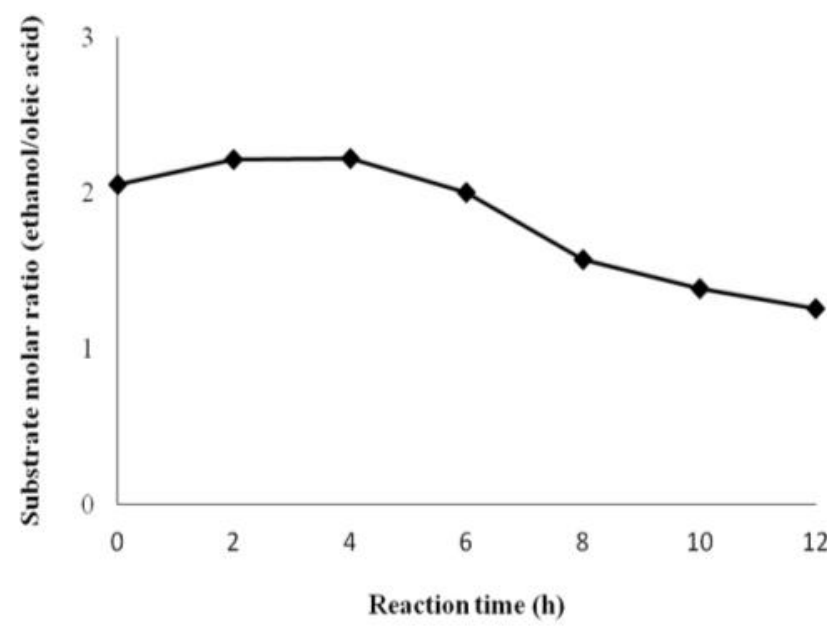

Figure 2. The substrate molar ratio (ethanol/oleic acid) ( $\diamond)$ during an enzymatic esterification reaction which was catalyzed using lipase from rice bran $(29.58 \mathrm{~g})$, carried out in the modified fed-batch system with the initial substrate molar ratio (ethanol/oleic acid) of 2.05:1, followed by the feeding of ethanol and oleic acid at $0.05 \mathrm{~mL} / \mathrm{min}$ and $0.26 \mathrm{~mL} / \mathrm{min}$, respectively, operated at $30^{\circ} \mathrm{C}$, at $1500 \mathrm{rpm}$ for $12 \mathrm{~h}$. added into the reaction system and, afterward, the final ester conversion was evaluated.

\subsection{Analysis}

Free Fatty Acid (FFA), OAEE, ethanol, water and the conversion of ester were calculated according to Lee et al. [14]; Prastowo et al. [5]; Segupta and Modak [15]; Barahona et al. [16], and Mat Radzi et al. [17], respectively.

\section{Results and Discussions}

\subsection{Effect of A Constant Ratio (Ethanol/ Oleic Acid) (2.05:1) on the Ester Synthesis}

The flow rates of ethanol and oleic acid into the reaction system were adjusted at 0.05 $\mathrm{ml} / \mathrm{min}$ and $0.26 \mathrm{~mL} / \mathrm{min}$, respectively, in which they were determined based on a substrate molar ratio (ethanol/oleic acid) of 1:1. By considering the equilibrium position of the reaction, feeding substrates at the ratio (ethanol/oleic acid) of 1:1 may first decrease the substrate molar ratio (ethanol/oleic acid) in the reaction system (previously adjusted at 2.05:1 at the initial reaction) to $3.05: 2$ [18]. As the reaction starts, the new ratio (3.05:2) may later increase to the initial ratio $(2.05: 1)$. This suggestion was proposed as the reaction of one mole of fatty acid and one mole of alcohol theoretically produces one mole of ester and one mole of water [18]. As the result, the substrate molar ratio was relatively constant at around 2.05:1 in the first $6 \mathrm{~h}$ of the reaction before decreasing to 1.25:1 in the last $6 \mathrm{~h}$ of the reaction (Figure 2).

Figure $3 \mathrm{~A}$ shows the ester conversion every $2 \mathrm{~h}$ during a $12 \mathrm{~h}$ esterification reaction. The production of ester increased drastically in the first $6 \mathrm{~h}$ of the reaction until it reached its peak at $76.8 \%$ (Figure $3 \mathrm{~A}$ ). It is suggested that the constant substrate molar ratio (ethanol/oleic acid) $(2.05: 1)$ in the first $6 \mathrm{~h}$ of the reaction may favor the work of lipase since it may provide the right amount of ethanol in the reaction system to avoid denaturizing the lipase $[5,8,19$, 20]. Consequently, the conversion rate may rise and result in a drastic increase in the ester conversion in the first $6 \mathrm{~h}$ of the reaction (76.8\%) (Figure 3A).

However, the reaction showed a decrease from $76.8 \%$ to $22.9 \%$ after the reaction took place for $6 \mathrm{~h}$ (Figure 3A). The production of water showed a similar trend to that of ester conversion (Figure 3A and Figure 3B), showing a drastic increase in the first $6 \mathrm{~h}$ of the reaction (reaching its peak at $6 \mathrm{~h}$ ) and then followed by a decrease $6 \mathrm{~h}$ later (Figure 3B). The similarity of both trends (Figure 3A and Figure 3B) is re- 
lated to the production of the final products at the same amounts (one mole of ester and of water) according to the equilibrium position of the reaction [18]. Thus, both trends (ester and water production) shared a similar trend (Figure 3A and Figure 3B).

The decrease in both (ester and water production) in the last $6 \mathrm{~h}$ of the reaction indicates that there was probably a reverse conversion of final products (ester and water) into early reactants (oleic acid and ethanol) by lipase (Figures 3A and 3B). This hypothesis may be caused by a drastic increase in the water production in the reaction system in the first $6 \mathrm{~h}$ of the reaction that may lead the lipase to hydrolyze the esterification product (esters) (Figure 3B). It is suggested that the interaction between the water and lipase structure at the molecular level may cause the lid protecting the active site of lipase to open widely [21]. Consequently, products (esters and water) may easily enter into the active site [9]. The carbonyl group of the ethyl ester is attacked by a nucleophilic hydroxyl group of the serine (active site) and forms an acyl-enzyme intermediate $[22,23]$. The intermediate is later attacked by a nucleophilic water molecule which then releases a fatty acid and an alcohol into the system [23]. Consequently, the equilibrium of esterification reaction may reverse and be shifted toward the formation of early reactants (oleic acid and ethanol), ultimately resulting in a decrease in the ester conversion and the production of water in the last $6 \mathrm{~h}$ of the reaction (Figures $3 \mathrm{~A}$ and $3 \mathrm{~B}$ ). The reaction shifting toward the formation of early reactants may also

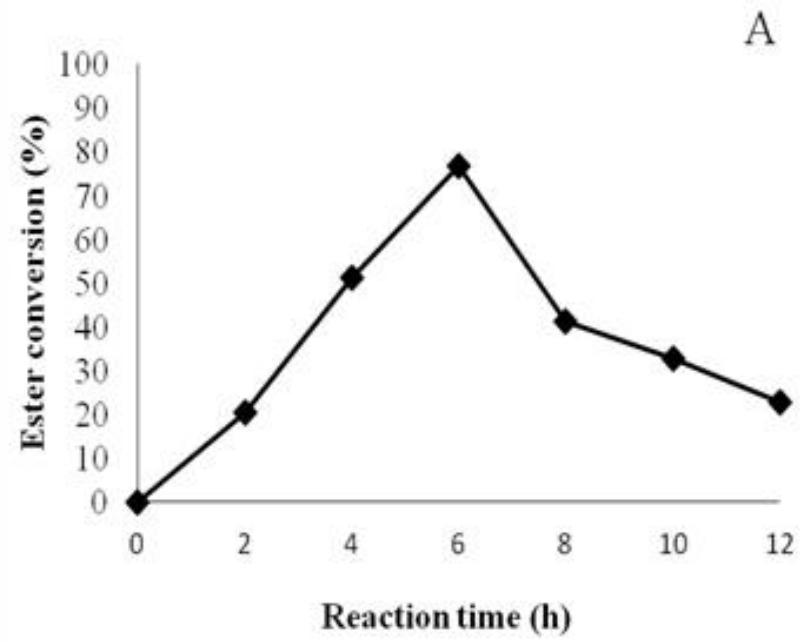

cause a decrease in the substrate molar ratio (ethanol/oleic acid) in the last $6 \mathrm{~h}$ of the reaction (Figure 2) since the reverse reaction may increase the concentration of ethanol and oleic acid in the reaction system.

\subsection{Effect of zeolite powder addition on the ester synthesis}

In order to overcome this problem, zeolite powder ( 25 and $50 \mathrm{mg} / \mathrm{mL}$ ) was added into the reaction system at $5 \mathrm{~h}$ of the reaction. Another experiment shows that the ester conversion increased slowly as the increase of water concentration until it reached its maximum conversion at $60 \%$ (Figure 4 ). When the concentration of water in the reaction system was higher than $60 \%$, the conversion decreased up to 2.3 times (Figure 4). Meanwhile, the concentration of water $(60 \%)$ was obtained when the esterification reaction took place for around $5 \mathrm{~h}$ (Figure $3 \mathrm{~A}$ ). Thus, zeolite powder (25 and $50 \mathrm{mg} / \mathrm{mL}$ ) was added into the reaction system at $5 \mathrm{~h}$ of the reaction.

The addition resulted in an increase in the final ester conversions of up to $90-95.7 \%$ (1.171.24 times) since zeolite powder may have absorbed water in the reaction system which may lead lipase to hydrolyze the final product (Figure 5). The differences in the final ester conversions (with and without zeolite powder addition) (Figure 5) also proved the hypothesis that water was involved in reducing the ester conversion [10, 11,12, 13, 21]. Furthermore, the absorbtion of water in the reaction system by zeolite powder may avoid the reverse conversion

Figure 3. The ester conversion (A) and the production of water (B) during an enzymatic esterification reaction which was carried out in the modified fed-batch system with the initial substrate molar ratio (ethanol/oleic acid) of 2.05:1, followed by the feeding of ethanol and oleic acid at $0.05 \mathrm{ml} / \mathrm{min}$ and 0.26 $\mathrm{ml} / \mathrm{min}$, respectively, operated at $30{ }^{\circ} \mathrm{C}$, at $1500 \mathrm{rpm}$ for $12 \mathrm{~h}$. 


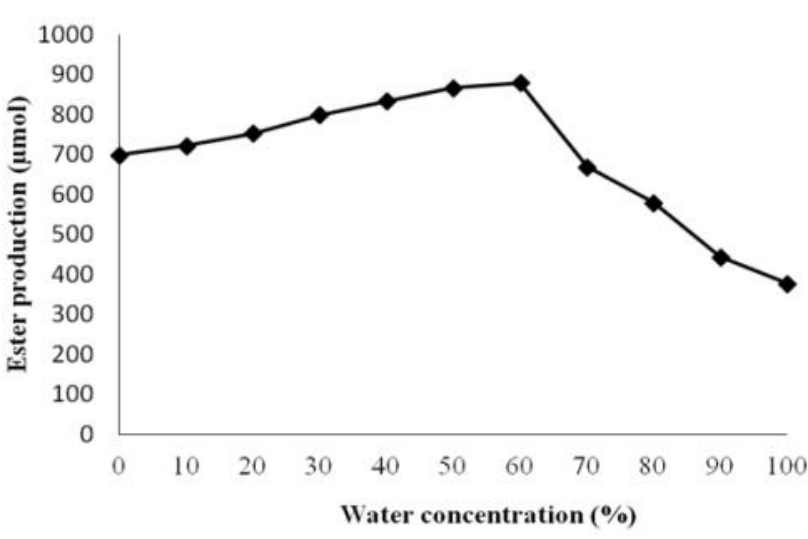

Figure 4. Ester production ( $\downarrow)$ during an enzymatic esterification reaction which was carried out in the modified fed-batch system with the initial substrate molar ratio (ethanol/oleic acid) of 2.05:1, followed by the feeding of ethanol and oleic acid at $0.05 \mathrm{~mL} / \mathrm{min}$ and $0.26 \mathrm{~mL} / \mathrm{min}$, respectively, operated at a room temperature $\left(30{ }^{\circ} \mathrm{C}\right)$ and then agitated at $1500 \mathrm{rpm}$ for $2 \mathrm{~h}$; with various water concentrations in the reaction system $(0,10,20,30,40,50$, 60, 70, 80, 90 and 100\%).

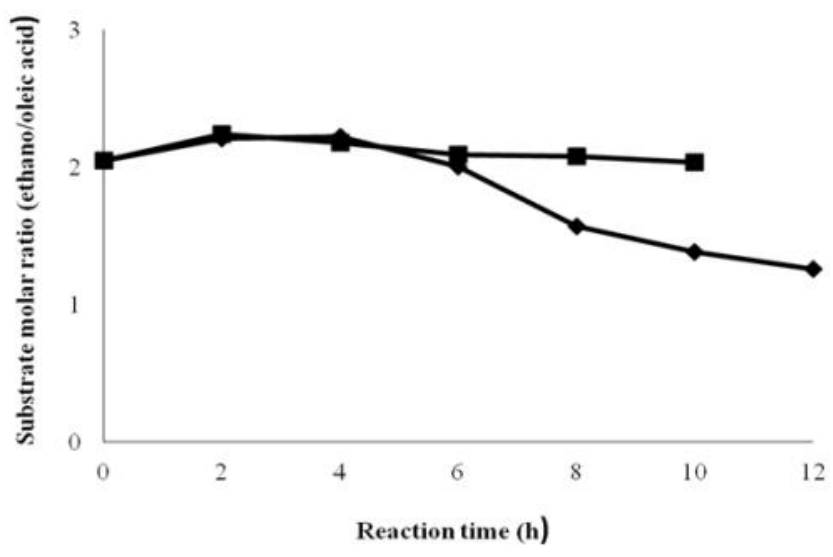

Figure 6. Substrate molar ratios (ethanol/oleic acid), before ( $\bullet$ ) and after ( $\boldsymbol{\square})$ the addition of zeolite powder $(50 \mathrm{mg} / \mathrm{mL})$ into the reaction system at $5 \mathrm{~h}$ of the reaction, during an enzymatic esterification reaction which was catalyzed using lipase from rice bran (29.58 g), carried out in the modified fed-batch system with the initial substrate molar ratio (ethanol/oleic acid) of 2.05:1, followed by the feeding of ethanol and oleic acid at $0.05 \mathrm{~mL} / \mathrm{min}$ and $0.26 \mathrm{~mL} / \mathrm{min}$, respectively, operated at $30{ }^{\circ} \mathrm{C}$, at $1500 \mathrm{rpm}$ for $12 \mathrm{~h}$.

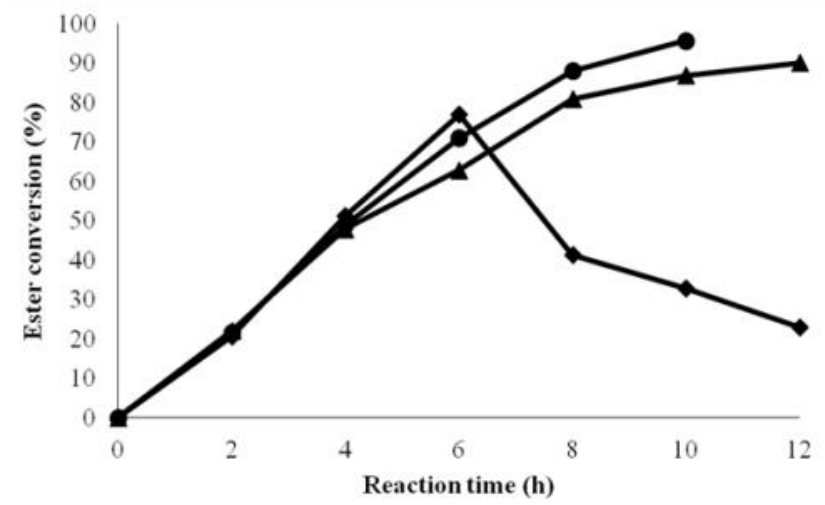

Figure 5. The ester conversions during an enzymatic esterification reaction which was carried out in the modified fed-batch system with the initial substrate molar ratio (ethanol/oleic acid) of $2.05: 1$, followed by the feeding of ethanol and oleic acid at $0.05 \mathrm{~mL} / \mathrm{min}$ and $0.26 \mathrm{~mL} / \mathrm{min}$, respectively, operated at $30{ }^{\circ} \mathrm{C}$, at $1500 \mathrm{rpm}$ for $12 \mathrm{~h}$; with the addition of zeolite powder at various concentrations: $25 \mathrm{mg} / \mathrm{mL}(\mathbf{\Delta})$ and 50 $\mathrm{mg} / \mathrm{mL}(\bullet)$ and without the addition of zeolite powder $(\star)$ into the reaction system at $5 \mathrm{~h}$ of the

and lead the reaction toward the formation of products. Thus, the accumulation of reactants (ethanol and oleic acid) in the reaction system which probably caused a decrease in the substrate molar ratio (ethanol/oleic acid) in the last $6 \mathrm{~h}$ of the reaction (Figure 2) could be reduced. This resulted in a relatively constant substrate molar ratio (ethanol/oleic acid) at around 2.05:1 during the reaction (Figure 6).

The combination of retaining a constant substrate molar ratio (ethanol/oleic acid) at 2.05:1 during the reaction and the addition of zeolite powder at 25 and $50 \mathrm{mg} / \mathrm{mL}$ into the reaction system increased the final ester conversions by up to $90-95.7 \%$ (Figure 5). The final ester conversion (95.7\%) was 1.04 times higher and obtained $2 \mathrm{~h}$ earlier than that of using the previous fed-batch system [6]. Moreover, this reaction system also produced a higher final ester conversion than any other esterification reactions using any other fed-batch systems [24, 25, $26,27]$.

\section{Conclusions}

The combination (the modified fed-batch system) of a constant substrate molar ratio (ethanol/oleic acid) during the reaction (at 2.05:1) with the addition of zeolite powder (25 and $50 \mathrm{mg} / \mathrm{mL}$ ) into the reaction system at $5 \mathrm{~h}$ resulted in higher final ester conversions (90$95.7 \%$ ). This was due to not only applying the 
appropriate amount of ethanol that may not denaturize lipase but also absorbing the water in the reaction system, which was hypothesized to lead lipase to reverse the esterification synthesis towards the formation of early reactants (ethanol and oleic acid).

\section{References}

[1] Petersson, A.E.V., Gustafsson, L.M., Nordblad, M., Borjesson, P., Mattiasson, B., Adlercreutz, P. (2005).Waxesters produced by solvent-free energy-efficient enzymatic synthesis and their applicability as wood coatings. Green Chem. 7,:837-843.

[2] Reetz, M T. (2002). Lipases as practical biocatalysts. Curr. Opin. Chem. Biol. 6(2): 145150.

[3] Aravindan, R., Anbumathi, P., \& Viruthagiri, T. (2007). Lipase applications in food industry. Indian J. Biotechnol. 6(2): 141-158

[4] Zhao, Y., Liu, J., Deng, L., Wang, F., \& Tan, T. (2011). Optimization of Candida sp. 99-125 lipase catalyzed esterification for synthesis of monoglyceride and diglyceride in solvent-free system. J. Mol. Catal. B-Enzym., 72(3): 157162

[5] Prastowo, I., Hidayat, C., \&Hastuti, P. (2012). Production and Optimization of Oleic Acid Ethyl Ester Synthesis Using Lipase From Rice Bran (Oryza sativa L.) and Germinated Jatropha Seeds (Jatropha curcas L.) by Response Surface Methodology. Indonesian $J$. Biotech., 17(1): 17 - 26.

[6] Hidayat, C., Prastowo, I., Hastuti, P., Restiani, R. (2014). Effect of ethanol concentrations on rice bran protease activity and ester synthesis during enzymatic synthesis of Oleic Acid Ethyl Ester in a fed-batch system using crude rice bran (Oryza sativa) lipase. Biocatal. Biotransfor., 32 (4): 231-235.

[7] Khamseh, A.A., Miccio, M. (2011). Comparison of batch, fed-batch and continuous well-mixed reactors for enzymatic hydrolysis of orange peel wastes. Proc. Biochem., 47 (11): 1588-1594.

[8] Shimada, Y., Watanabe, Y., Sugihara, A., \& Tominaga, Y. (2002). Enzymatic alcoholysis for biodiesel fuel production and application of the reaction to oil processing. J. Mol. Catal. B-Enzym., 17(3): 133-142.

[9] Grochulski, P., Li, Y., Schrag, J.D. and Cygler, M. (1994). Two conformational states of Candida rugosa lipase. Prot. Sci. 3: 82-91.

[10] Lie, E., Molin, G. (1991). Hydrolysis and esterification with immobilized lipase on hydrophobic and hydrophilic zeolites. $J$. Chem. Tech. Biotechnol. 50(4): 549-553.
[11] Beers, A.E.W., Spruijt, R.A., Nijhuis, T.A., Kapteijn, F., Moulijn, J.A. (2001). Esterification in a structured catalytic reactor with counter-current water removal. Catal. Today, 66(2): 175-181.

[12] Tanaka, K., Yoshikawa, R., Ying, C., Kita, H., Okamoto, K.I. (2001). Application of zeolite membranes to esterification reactions. Catal. Today, 67(1): 121-125.

[13] Nijhuis, T.A., Beers, A.E.W., Kapteijn, F., Moulijn, J.A. (2002). Water removal by reactive strripping for a solid-acid catalyzed esterification in a monolithic reactor. Chem. Eng. Sci., 57(9): 1627-1632.

[14] Lee, J. H., Kim, S. B., Yoo, H. Y., Lee, J. H., Han, S. O., Park, C., \& Kim, S. W. (2013). Coimmobilization of Candida rugosa and Rhyzopus oryzae lipases and biodiesel production. Korean J. Chem. Eng., 30 (6): 1335-1338.

[15] Sengupta, S., \& Modak, J. M. (2001). Optimization of fed-batch bioreactor for immobilized enzyme processes. Chem. Eng. Sci., 56(11): $3315-3325$

[16] Barahona, D., Pfromm, P. H., Rezac, M. E. (2006). Effect of water activity on the lipase catalyzed esterification of geraniol in ionic liquid [bmim] PF6. Biotechnol. Bioeng., 93(2): 318-324.

[17] Mat Radzi, S., Basri, M., Bakar Salleh, A., Ariff, A., Mohammad, R., Abdul Rahman, M B., \& Abdul Rahman, R. N. Z. R. (2005). High performance enzymatic synthesis of oleyloleate using immobilised lipase from Candida Antarctica. Electron. J. Biotechn., 8(3): 291-298

[18] Oliveira, A.C., Rosa, M.F., Aires-Barros, M.R., Cabral, J.M.S. (2001). Enzymatic esterification of ethanol and oleic acid- a kinetic study. $J$. Mol. Catal. B-Enzym., 11: 999-1005.

[19] Shieh, C. J., Liao, H. F., \& Lee, C. C. (2003). Optimization of lipase-catalyzed biodiesel by response surface methodology. Bioresource Technol., 88(2): 103-106.

[20] Nie, K., Xie, F., Wang, F., \& Tan, T. (2006). Lipase catalyzed methanolysis to produce biodiesel: optimization of the biodiesel production. J. Mol. Catal. B-Enzym., 43(1): 142-147.

[21] Brzozowski, A.M., Derewenda, U., Derewenda, Z.S., Dodson, G.G., Lawson, D.M., Turkenburg, J.P., Bjorkling, F., Huge-Jensen, B., Patkar, S.A. and Thim, L. (1991). A model for interfacial activationin lipases from the structure of a fungal lipase-inhibitor complex. Nature 351: 491-494.

[22] Ollis, D.L., Cheah, E., Cygler, M., Dijkstra, B., Frolow, F., Franken, S.M., Harel, M., Remington, S.J., Silman, I., Schrag, J., Sussman, J.L., Verschueren, K.H.G. and Goldman, A. (1992) The alpha/beta hydrolase fold. Prot. Eng. 5: 197-211. 
[23] Ribeiro, B. D., Casto, A. M. D., Coelho, M.A.Z., Freire, D. M. G. (2011). Production and use of lipases in bioenergy: a review from feedstocks to biodiesel production. Enzym. Res., 2011: 1-16.

[24] Soultani, S., Engrasser, J. M., Ghoul, M. (2001). Effect of acyl donor chain length and sugar /acyl donor molar ratio on enzymatic synthesis of fatty acid fructose esters. J. Mol. Catal. B-Enzym., 11(4): 725-733.

[25] Kim, P-Y., Pollard, D.J., Woodley, J. M. (2007). Substrate supply for effective biocatalysis. Biotechnol. Progress., 23 (1): 7482 .
[26] Pyo, S. H., Hayes, D. G. (2009). Designs of bioreactor systems for solvent-free lipasecatalyzed synthesis of fructose-oleic acid esters. J. Am. Oil Chem. Soc, 86(6): 521-529.

[27] Ye, R., Pyo, S. H., Hayes, D. G. (2010). Lipasecatalyzed synthesis of saccharide-fatty acid esters using suspensions of saccharide crystals in solvent media. J. Am. Oil Chem. Soc., 87 (3): 281-293. 